\title{
Restrictions on Religions due to the COVID-19 Pandemic
}

\section{Responses of Religious Communities in Bosnia and Herzegovina}

\author{
Nedim Begović \\ University of Sarajevo, Sarajevo, Bosnia and Herzegovina \\ nedim.begovic@fin.unsa.ba
}

\begin{abstract}
This article explores the restrictions that have been recently placed on religions in Bosnia and Herzegovina on congregating and conducting religious rituals during the COVID-19 pandemic, as well as the perceptions and responses of the main religious communities to these restrictions. Our data sources included the state CoviD-19 regulations, the guidelines of religious communities regarding worship services, congregational prayers, and other activities during the pandemic, and media articles covering religion and the COVID-19 issues on a domestic and regional scale. Our research has shown that not all religious communities have been equally supportive of state regulations that restricted the religious freedom of individuals and religious communities. Their responses have ranged from strict harmonization of internal religious guidelines with the state COVID-19 regulations to declarative support of public health recommendations while ignoring them in practice.
\end{abstract}

\section{Keywords}

restrictions - religious communities - congregational prayers - worship - religious gatherings - COVID-19

The global outbreak of the coronavirus (COVID-19) pandemic raised several questions at the crossroads of religion, state, and law. In the absence of a vaccine or antiviral drug against COVID-19, the global prevention strategy relies 
on reducing social interactions and maintaining physical distance between people, which includes the suspension of mass gatherings. ${ }^{1}$ This inevitably leads to restrictions on religious groups to worship or conduct public religious rituals. International human rights treaties assert that the right to freedom of religion has both individual and collective dimensions, ${ }^{2}$ the latter being severely jeopardized if believers are prevented from practicing and sharing their beliefs in common. During the Covid-19 pandemic, however, such gatherings can spread the disease, endangering not only participants but also people interacting with them. ${ }^{3}$ The protection of health is a valid ground for restricting religious freedom, but two more criteria must be met for the legitimacy of any such restriction: the restriction must be necessary and prescribed by law. ${ }^{4}$ The question arises: to what extent may state safety measures for the prevention of the epidemic legitimately encroach upon religious freedom? Another set of questions concerns the attitudes of religious communities toward restrictions of their ability to worship and conduct religious services during the pandemic. How these communities use theological arguments and religious canons to justify compliance with state regulations? How did the pandemic change the priorities of religious communities and transformed their religious life?

Recent experiences with other pandemics (e.g., the Ebola virus) attest to the important role of religious actors and faith-based organizations in successfully preventing the spread of infection. This is particularly relevant for societies with high degrees of religiosity and trust in religious communities. A recent Pew Research Center survey has shown that Bosnia and Herzegovina (BiH) is the 6th most religious of 34 European countries. ${ }^{5}$ Another study has found that Bosnian citizens show the greatest trust in the religious institutions (around $77 \%$ ), with similar ratings for entities of the Federation of Bosnia and Herzegovina $(\mathrm{FBiH})(75 \%)$ and Republika Srpska (RS) (78\%). The study has also

1 See World Health Organization, 14 April 2020 COVID-19 Strategy Update (2020), 9.

2 See e.g. Article 18 para. 1, International Covenant on Civil and Political Rights (ICCPR). 1966. Retrieved 1 May 2020, https://www.ohchr.org/en/professionalinterest/pages/ccpr.aspx; Article 9 para. 1, European Convention on Human Rights (ECHR). 1950. Retrieved 1 May 2020, https://www.echr.coe.int/Documents/Convention_ENG.pdf.

3 Gayle Manchin and James W. Carr, "Covid-19 Symposium: Don't Let Religious Freedom Become a Casualty of Coronavirus" 2020. Retrieved 1 May 2020, https://opiniojuris.org/2020/ 04/o6/covid-19-symposium-dont-let-religious-freedom-become-a-casualty-of-coronavirus/.

4 Article 18 para. 2 of the ICCPR and Article 9 para. 2 of the ECHR.

5 See Jonathan Evans and Chris Baronavski, "How do European countries differ in religious commitment? Use our interactive map to find out" 2018. Retrieved 1 May 2020, https:// www.pewresearch.org/fact-tank/2018/12/05/how-do-european-countries-differ-in-religious -commitment/). 
shown almost continuous rise of trust in religious communities from 2009 through 2017..$^{6}$ These results illustrate the power of religious communities to influence the attitudes of believers toward the pandemic.

This article investigates the effect of state COVID-19 regulations introduced in $\mathrm{BiH}$ on religious freedom, in particular on the ability of religious communities to worship and conduct religious rituals. It analyzes the responses to these restrictions of the four traditional religious communities in $\mathrm{BiH}$ : the Islamic Community (IC), the Serbian Orthodox Church (SOC), the Catholic Church (CC) and the Jewish Community (JC). The article draws on the state regulations, religious community guidelines and activities during the pandemic, and media articles covering issues of religion and CoviD-19 to determine the extent to which Bosnian religious leaders and institutions have succeeded in translating the state health recommendations into a theological discourse capable of mobilizing the religious conscience of believers and shaping their attitudes toward the pandemic.

First, we present state COVID-19 regulations affecting religion (Section 2) and examine their compatibility with the constitutional guarantees of the right to freedom of religion (Section 3). A detailed analysis of guidelines of the religious communities during the pandemic (section 4 ) is followed by a discussion of theological and religious arguments in favor of compliance with state Covid-19 regulations.

The research shows that the responses of the four religious communities in $\mathrm{BiH}$ to state health recommendations ranged from strict compliance to declarative support not necessarily accompanied by practical implementation.

\section{State COVID-19 Regulations Affecting Religious Gatherings}

On March 11, 2020, the World Health Organization (wHO) declared a global pandemic caused by the spread of the coronavirus (SARs-CoV-2) and called all national governments to "take urgent and aggressive action" to prevent infection, save human lives, and minimize social and economic effects. ${ }^{7}$ Responding to the wHO recommendations and following the development of the epidemiological situation, the authorities of $\mathrm{BiH}$ promptly adopted the

6 Božo Skoko and Dejan Lučka, Povjerenje u medije i medijske slobode [Trust in the Media and Media Freedoms] (2017), 19-20.

7 "WHO Director-General's opening remarks at the media briefing on COVID-19-11 March 2020" 2020. Retrieved 25 April 2020, https://www.who.int/dg/speeches/detail/who-director-general -s-opening-remarks-at-the-media-briefing-on-covid-19---11-march-2020. 
necessary regulations, using domestic legislative framework to respond to the challenge of the CoviD-19 pandemic.

The fragmented systems of healthcare ${ }^{8}$ and the protection of life and property in times of natural and other disasters, including "the epidemics of infectious diseases"9 in $\mathrm{BiH}$, are a reflection of the complex, decentralized, and ethnically sensitive constitutional order established by the Dayton Peace Agreement in 1995, which ended the war in $\mathrm{BiH}(1992-1995) \cdot{ }^{10}$ All the activities of public authorities aimed to prevent or slowdown the coronavirus pandemic are managed and coordinated not at the state-level but at the level of the two entities and the вD BiH. Coordination of state and entity measures and activities to combat the pandemic is among the tasks of the coordinating body of $\mathrm{BiH}$ for protection and rescue from natural or other disasters. In practice, however, the coordination has been rather weak, at least as far as harmonization of measures adopted to prevent the spread of the disease is concerned.11 Authorities of the Rs have relied greatly on the approaches of the Serbian government in managing the pandemic, which had some consequences for statereligion relations during the pandemic, in particular in case of the soc.

8 The healthcare in $\mathrm{BiH}$ is under the jurisdiction of the two entities: Republic of Srpska (RS) and the Federation of Bosnia and Herzegovina ( $\mathrm{FBiH})$, together with the Brčko District of Bosnia and Herzegovina (BD BiH). See Ervin Mujkić, „Sistem zdravstva u Bosni i Hercegovini: stanje i pravci moguće reforme" [The Healthcare System in Bosnia and Herzegovina: the Current Situation and the Directions of Possible Reform], 2 Sveske za javno pravo (2011), 46 .

9 The system of protection of life and property in emergency situations, i.e., in a natural or other disaster, is primarily the responsibility of the entities and the BD BiH. Some of the authority is distributed to local self-government units (municipalities and cities) in both entities, as well as to cantons in the FBiH.

10 The General Framework Agreement for Peace in BiH was negotiated in Dayton (US) and signed on 14 December 1995, in Paris (France). Annex 4 to this Agreement is the Constitution of $\mathrm{BiH}$, which defines $\mathrm{BiH}$ as a complex state composed of two entities: $\mathrm{FBiH}$ and Rs. The FBiH is divided into 10 cantons consisting of municipalities, whereas the RS is structured administratively on a municipal basis. The International Arbitral Award of 1999 established the $\mathrm{BD} \mathrm{BiH}$ as a separate administrative unit of local self-government that does not belong to either entity and is under the sovereignty of BiH (See Nedim Begović, "Ustavni okvir i Zakon o slobodi vjere i pravnom položaju crkava i vjerskih zajednica u $\mathrm{BiH}^{\prime}$ [Constitutional Framework and the Law on Freedom of Religion and the Legal Status of Churches and Religious Communities in $\mathrm{BiH}]$, in Edin Šarčević and Drago Bojić (eds.), Sekularnost i religija: BiH i regija (2015), 72-73.

11 "Predsjedništvo BiH: Harmonizirati mjere na nivou države, Rs ostaje u karantinu“ [Presidency of BiH: To harmonize the measures at the state level; the RS remains under quarantine] 2020. Retrieved 10 May 2020, https://avaz.ba/vijesti/bih/56639o/predsjednistvo -bih-harmonizirati-mjere-na-nivou-drzave-rs-ostaje-u-karantinu. 
On the initiative of the Presidency of $\mathrm{BiH},{ }^{12}$ on March 17, 2020, the Council of Ministers of $\mathrm{BiH}(\mathrm{CM} \mathrm{BiH})$ adopted the decision declaring "the occurrence of a state of natural or other disaster in the territory of Bosnia and Herzegovina owing to the danger of the possible outbreak of an infectious disease caused by a new coronavirus (COVID-19)."13 Previously, the FBiH government and the Mayor of the BD BiH adopted similar decisions within their jurisdictions. ${ }^{14} \mathrm{On}$ March 16, 2020 the FBiH declared a state of disaster, and on March 28, 2020, the RS declared a state of emergency. The central role in activities to protect public health during the COviD-19 threat was assigned to the Federal Headquarter of Civil Protection (FHCP) in the $\mathrm{FBiH}^{15}$ and the Republican Headquarter for Emergency Situations (RHES) in the Rs. ${ }^{16}$

Entity headquarters adopted a series of orders, recommendations, and conclusions aimed at protecting public health and managing the crisis. These measures are referred to below as the state coviD-19 regulations, some of which restrict the right to freedom of religion or belief guaranteed by the constitutions of the country and entities.

Two somewhat different regulatory approaches can be noticed in the COVID-19 measures of the two entities when it comes to the imposition of restrictions on religions. In the $\mathrm{FBiH}$, no specific regulations were adopted on restricting religious events and practices, but rather general regulations, such as curfews, that affected religious communities indirectly. Religions were affected by FHCP orders restraining freedom of movement and assembly, including (a) the suspension of all public gatherings, ${ }^{17}$ (b) the ban on movement of people between 8 p.m. and 5 a.m. (so-called curfew), ${ }^{18}$ and (c) the ban on the

12 "Održana 56. vanredna sjednica Predsjedništva BiH [The 56 th extraordinary session of the Presidency of BiH was held] 2020. Retrieved 3 May 2020, http://www.predsjednistvo bih.ba/zaklj/sjed/default.aspx?id=87855\&langTag=bs-BA.

13 Decision to declare the occurrence of a state of natural or other disaster in the territory of Bosnia and Herzegovina, Official Gazette of BiH, 18/20.

14 Decision to declare the endangerment of the population of the BD BiH from the epidemic of infectious diseases - the coronavirus (COVID-19).

15 Article II, Decision to declare the state of disaster caused by the emergence of the coronavirus (COVID-19) in the territory of the Federation of Bosnia and Herzegovina, Official Gazette of the $\mathrm{FBiH}, 21 / 20$.

16 The Decision to declare the emergency situation in the territory of the Republic of Srpska, Official Gazette of the RS, 25/20.

17 Federal Headquarter of Civil Protection, Order no. 12-40-6-148-9/20 of 17 March 2020. Retrieved 13 May 2020, http://fbihvlada.gov.ba/file/o8_NAREDBA-broj-12-40-6-148-9.pdf. The validity of this order has been extended until further notice (Order no. 12-40-6-148-91/20, 27 March 2020. Retrieved 13 May 2020, http://fbihvlada.gov.ba/file/275.pdf).

18 Federal Headquarter of Civil Protection, Order no. 12-40-6-148-36-1/20 of 29 March 2020. Retrieved 13 May 2020, http://fbihvlada.gov.ba/file/Naredba\%2036-1.pdf. The ban was 
movement of persons under the age of 18 and over $65 \cdot{ }^{19}$ Generally, these regulations have limited the ability of religious communities to conduct congregational prayers and perform religious services. Additionally, the suspension of school on the order of the Federal Ministry of Healthcare, included the schools and seminaries of religious communities. ${ }^{20}$

In the $\mathrm{RS}$, in addition to general regulations restricting freedom of assembly and of movement, ${ }^{21}$ specific religion-related measures have also been adopted, although framed as recommendations. The RHES conclusion "on restricting assemblies in places of worship" recommended

... to the authorities of recognized churches and religious communities to adjust their rituals and other worship services in accordance with measures to prevent the spread of the new coronavirus. ${ }^{22}$

removed by the Order no. 12-40-6-148-145/20 of 24 April 2020. Retrieved 13 May 2020, http://fbihvlada.gov.ba/file/NAREDBA\%20145.pdf.

19 Federal Headquarter of Civil Protection, Order no. 12-40-6-148-34/20 of 20 March 2020. Retrieved 13 May 2020, http://fbihvlada.gov.ba/file/27naredba.pdf. This Order was partially modified by the new Order no. 12-40-6-148-143/20 of 24 April 2020 (retrieved 13 May 2020, http://fbihvlada.gov.ba/file/3_NAREDBA\%20143.pdf), which prescribes the ban on movement of persons under 18 and above 65 years, except at specified hours during the week.

20 Crisis Headquarter of Federal Ministry of Healthcare, Order no. 01-33-1426/20 of 11 March 2020. Retrieved 13 May 2020, https://covid19.fmoh.gov.ba/uploads/files/Naredba-1103 -b8a3c934f36o693cd651f23a8c7b4545123ec2ef.pdf.

21 Similarly to the $\mathrm{FBiH}$, regulations were adopted banning all public gatherings, prohibiting the movement of citizens from 8 p.m. to 5 a.m., prohibiting the movement of persons over 65 years of age, and introducing compulsory quarantine for travelers entering BiH. Additionally, citizens' movement on weekends was banned on several occasions. See "Dodik potvrdio: Republika Srpska uvodi policijski sat od 20 do 5 sati“ [Dodik confirmed: Republic of Srpska is introducing the curfew from 20:00 till 5:00] 2020. Retrieved 27 April 2020, https://www.tportal.hr/vijesti/clanak/dodik-potvrdio-republika-srpska-veceras-uvodi -policijski-sat-20200321; „Republički štab za vanredne situacije Rs: Donijet Zaključak o zabrani kretanja u dane vikenda od subote u 12:00 časova do nedjelje u 18:0o časova" [Republican Headquarter for Emergency Situations Rs: A Conclusion was adopted to ban movement on weekend, from Saturday 12:00 till Sunday 18:00] 2020. Retrieved 27 April 2020, https://www.paragraf.ba/dnevne-vijesti/o6042020/06042020-vijest3.html; Republican Headquarter for Emergency Situations, Conclusion on the obligatory enforcement of measures to respond to the emergence of the disease caused by a new coronavirus (covid-19) in the Repulic of Srpska. 2020. Retrieved 27 April 2020, https://www.paragraf .ba/propisi/republika-srpska/zakljucak-o-obaveznom-sprovodjenju-mjera-za-reagovanje -na-pojavu-bolesti-izazvane-novim-virusom-korona-covid-19-u-republici-srpskoj.html.

22 Republican Headquarter for Emergency Situations, Conclusion on restriction of assembly in places of worship of 21 March 2020, para. 2. Retrieved 26 April 2020, https://www.para graf.ba/propisi/republika-srpska/zakljucak-o-ogranicenju-okupljanja-u-vjerskim-objek tima.html. 
Carefully selected terminology in this recommendation reveals the reluctance of the authorities to impose restrictions on worship and religious gatherings, preferring instead cooperation with the religious communities. ${ }^{23}$ Such a cooperative approach was evident in both entities, although it had an additional dimension in the Rs, resulting from the dominant position and the influence of the soc.

Another specific regulation imposing a restriction on freedom of religion in the RS was the RHES prohibition of movement on Easter, between Friday, 17 April at 3 p.m. and Saturday, 18 April at 5 a.m., and from Saturday, 18 April at 3 p.m. to Monday, 20 April at 5 a.m. Its objective was to prevent the expected increase inholiday travel. ${ }^{24}$

\section{Compatibility of the State covid-19 Regulations with the Constitutional Guarantees of the Right to Freedom of Religion}

As noted above, state COVID-19 regulations preventing public gatherings and restricting movement of people constitute an interference with the human right to freedom of religion, as guaranteed by the constitutional law of $\mathrm{BiH} .{ }^{25}$ The basic guarantees of religious freedom in $\mathrm{BiH}$ are enshrined in the constitutions of the country and the two entities, as well as the Statute of the BD BiH. These are further elaborated by the Law on freedom of religion and the legal status of churches and religious communities, ${ }^{26}$ the body of developing caselaw, and bilateral treaties between the state and religious communities. ${ }^{27}$

According to the Constitution of $\mathrm{BiH}$, both the state and the entities "shall ensure the highest level of internationally recognized human rights and fundamental freedoms, ${ }^{28}$ including freedom of thought, conscience, and religion. ${ }^{29}$

23 Republican Headquarter for Emergency Situations, Conclusion on restriction of assembly in places of worship of 21 March 2020, para. 2-3.

24 Republican Headquarter for Emergency Situations, Conclusion on the prohibition of movement in the days of Easter. 2020. Retrieved 27 April 2020, https://www.paragraf.ba/ propisi/republika-srpska/zakljucak-o-zabrani-kretanja-u-dane-vaskrsa.html.

25 Article II para. 3 subpara. g), i) and m) of the Constitution of BiH. 1995. Retrieved 3 May 2020, http://www.ccbh.ba/public/down/USTAV_BOSNE_I_HERCEGOVINE_engl.pdf.

26 Law on freedom of religion and the legal status of churches and religious communities, Official Gazette of BiH, $5 / 04$.

27 For more details, see Ahmet Alibašić and Nedim Begović, "Reframing the Relations between State and Religion in Post-War Bosnia: Learning to be Free!", 19 Journal of Balkan and Near Eastern Studies (2017), 19-34.

28 Article II para. 1, Constitution of BiH.

29 Article II para. 3 subpara. g), Constitution of BiH. 
The same article provides that the rights and freedoms recognized by the ECHR and its protocols shall directly apply to $\mathrm{BiH}$ and shall have priority over all other laws. ${ }^{30}$ Individuals and religious communities may directly refer to the provisions of the Convention before the domestic courts in matters of religious freedom. ${ }^{31}$

The European Court of Human Rights (ECtHR) suggests that the protection of public health is a particularly compelling reason for restricting religious freedom. ${ }^{32}$ This, however, does not relieve parties to the ECHR of the obligation to carefully balance the conflicting interests of protecting public health and the fundamental right to freedom of religion. Michelle Bachelet, the UN High Commissioner for Human Rights, has emphasized "the imperative of respect for civil and political rights" during the crisis caused by the spread of COVID-19. Declaring an emergency situation to combat the pandemic makes it easier for governments to adopt the necessary measures and respond quickly to the changing conditions of the pandemic. But "an emergency situation is not a blank check to disregard human rights obligations." ${ }^{33}$

To date, there have been no complaints against COVID-19 regulations before domestic courts for their restrictive effect on religions. But the Constitutional Court of $\mathrm{BiH}$ considered the issue of compliance of the domestic CoviD-19 regulations with freedom of movement provisions of the Constitution and the ECHR. ${ }^{34}$ In case AP-1217/20, the Court found that the orders of the FHCP banning the movement of persons under the age of 18 and over 65 violated the petitioner's right to freedom of movement under Article II para. 3. subpar. m) of the Constitution of $\mathrm{BiH}$, and Article 2 of the Protocol no. 4 to the ECHR, and of all persons in the same factual situation. The Court did not accept the petitioner's request, however, for the revocation of the FHCP orders "given the current situation and the fact that there is a great public interest for introducing certain restrictions." Instead, it gave Headquarters the opportunity to make the orders conform to the constitutional human rights provisions. The reasoning of the Court enables us to derive the criteria that should be taken into consideration by public authorities when imposing restrictions on human rights, including

\footnotetext{
$30 \quad$ Article II para. 2, Constitution of BiH.

31 Supra note 10, p. 4.

32 See Manfred Nowak and Tanja Vospernik, "Permissible Restrictions of Religion or Belief", in: Tore Lindholm et al. (eds.), Facilitating Freedom of Religion or Belief: A Deskbook (2004), 157-158.

33 Covid-19 pandemic - Informal briefing to the Human Rights Council: Statement by Michelle Bachelet, UN High Commissioner for Human Rights, 9 April 2020. Retrieved 27 April 2020, https://www.ohchr.org/en/newsevents/pages/displaynews.aspx.

Article 5 para. 1., ECHR; Article II para. 3 subpara. m), Constitution of BiH.
} 
the right to freedom of religion, with the aim to protect the health of the community from the COVID-19 and other infectious diseases. First, the restrictive measure should be accompanied by a valid explanation from health experts confirming its necessity. Second, less restrictive measures are to be considered first, if they are sufficient to achieve the legitimate aim. Finally, public authorities are required to specify the time frame in which the restrictive measures are to be applied, making it necessary to continually reconsider the proportionality of these measures to the legitimate public health concerns. ${ }^{35}$

It may be argued that the COVID-19 regulations restricting religious assemblies satisfied the three-pronged test that the ECHR Article 9(2) sets out for the legitimacy of interference into the right to freedom of religion. They were prescribed by relevant laws regulating public gatherings and the protection of the population from infectious diseases; had the legitimate aim of protecting the health of the population; and were necessary to prevent mass gatherings.

These regulations did not treat religious gatherings more severely than secular assemblies. In the $\mathrm{FBiH}$, general regulations on cancellation of public gatherings have been applied equally to secular and religious events. In the Rs, religious gatherings were favored over the secular ones, as the RHES conclusion recommended (did not order) the adaptation of worship to the conditions of the CoviD-19 pandemic. In considering proportionality, we bear in mind that the performance of religious rites and worship was not entirely forbidden. ${ }^{36}$ Of the criteria of the Constitutional Court in case AP-1217/20, the lack of a precise time frame for the cancellation of public gatherings, including religious ones, reduces the normative quality of the FHCP regulations and potentially raises doubts about their compatibility with the proportionality principle.

\section{Responses by Religious Communities to Constraints Imposed on Religious Gatherings and Rituals}

Bosnians identify themselves as Muslims $(1,790,454$ or $50.7 \%)$, Orthodox $(1,085,760$ or $30.7 \%)$ and Catholics $(536,333$ or $15.2 \%)$. The rest of the

35 Constitutional Court of BiH, Case AP-1217/20, Decision on admissibility and meritum, April 22, 2020, para. 63, 66, 67. Retrieved 11 May 2020, http://www.ustavnisud.ba/doku menti/_bs/AP-1217-20-1234093.pdf.

36 Harun Išerić, „Koronavirus u pravnom poretku BiH: kratka dijagnoza bolesti“ [Coronavirus in the Legal Order of BiH: Short Diagnosis of the Disease], 2020. Retrieved 15 June 2020, http://www.fcjp.ba/analize/Harun_Iseric6-Koronavirus_u_pravnom_poretku_BiH -kratka_dijagnoza_bolesti.pdf. 
population includes members of other religions, atheists, agnostics, and those who have not declared their religious affiliation. ${ }^{37}$ Our discussion of religious responses to the COVID-19 regulations includes the four traditional religious communities of which three are dominant, and the JC, which is a minority religion. These communities are represented in the Interreligious council in $\mathrm{BiH}$, a non-governmental organization established in 1997 to help build civil society through various projects of interreligious dialogue. ${ }^{38}$

\subsection{The Islamic Community}

The IC was the first religious community in BiH to respond to the CoviD-19 pandemic. Relying on its authority among members of the Bosnian Muslim community, the IC has firmly taken the position that its faithful should strictly adhere to the measures taken by the competent state bodies in response to the outbreak of the pandemic. Since the wHO declaration of the global Covid-19 pandemic and the first measures adopted by state authorities to prevent the spread of the infection, the IC gradually adapted its religious activities to the new situation and provided timely information to its members on all developments in this regard. The internal guidelines on the operation of the IC during the pandemic were prepared by its highest religious and administrative authorities, namely ra'is al-'ulama', the Riyasat, and the Council of Muftis. ${ }^{39}$ Note that the IC approach to the state safety measures for the prevention of the spread of COVID-19 has generally been rated positive and proactive, based on the reported encounters of ra'is al-'ulama' with the state representatives. ${ }^{40}$ From the outbreak of the COVID-19 pandemic, the adaptation of religious activities within the IC has gone through three stages.

Agency for Statistics, Popis stanovništva, domaćinstava i stanova u Bosni i Hercegovini, 2013.: Rezultati popisa [Cenzus of Population, Households and Dwellings in Bosnia and Herzegovina, 2013: Final Results] (2016), 68.

38 „O nama“ [About us]. Retrieved 5 May 2020, https://www.mrv.ba/lat/o-nama.

39 The Riyasat is the highest executive body for religious, educational, economic, financial, legal, and other affairs of the IC. See Arts. 55, 6o and 61, Constitution of the IC in BiH consolidated text. 2014. Retrieved 5 May 2020, https://static.islamskazajednica.ba/imag es/stories/Ustavi/Ustav_IZ-e_precisceni_tekst_2014.pdf.

40 See e.g. "Reisu-l-ulema sa pomoćnikom ministra zdravlja Federacije Bosne i Hercegovine" [Ra'is al-'ulama' with the Assistant to the Minister of Healthcare of the Federation of Bosnia and Herzegovina] 2020. Retrieved 5 May 2020, https://static.islamskazajednica.ba/ aktivnosti-reisu-l-uleme/28939-reisu-l-ulema-sa-pomocnikom-ministra-zdravlja-feder acije-bosne-i-hercegovine; „Reisu-l-ulema i ministar Radončić o širenju koronavirusa“ [Ra'is al-'ulama' and minister Radončić on the spread of the coronavirus] 2020. Retrieved 5 May 2020, https://avaz.ba/vijesti/bih/556107/reisu-l-ulema-i-ministar-radoncic-o-sirenju -koronavirusa. 
In the first stage, which generally corresponds to the time before the declaration of the state of disaster, the IC continued conducting daily ${ }^{41}$ and Friday prayers with precautionary measures against the spread of infection (disinfection of mosques, shortening Friday sermons, etc.), in accordance with initial recommendations of the public health authorities. ${ }^{42}$ These measures were enumerated in the Instruction of March 12, 2020 - issued by Husein Kavazović, ra'is al-'ulama' of the IC - about performing congregational prayers and other religious activities during the pandemic of COVID-19. ${ }^{43}$

Ra'is al-'ulama' urged the faithful to the utmost accountability and concern for one's own health and the health of others, and adherence to all measures of prevention, precaution, responsible behavior and recommendations issued by the competent institutions. ${ }^{44}$

The next stage, following the declaration of the state of disaster or emergency and enacting more restrictive CoviD-19 regulations, involved the suspension of congregational prayers, including the Jumu'a prayer on Fridays, as well as other mosque gatherings. The suspension was grounded on the recommendations of the IC Council of Muftis of March 17, 2020, which pointed also to the need "to preserve symbolically the institution of the Jumu'a prayer without endangering the lives of people." This could be achieved by the imam performing the Jumu'a prayer with a small number of members of the local congregation (jama'at), conforming to the regulations on public gatherings. Persons at risk (the elderly, chronic patients, etc.) were asked not come to the mosque. ${ }^{45}$ The recommendations of the Council of Muftis were further elaborated by the Instruction of Ra'is al-'ulama' of March 18, 2020, for imams and mosque

41 There are five daily prayers in Islam.

42 Supra note 20; Order no. 01-33-1472/20 of 12 March 2020. Retrieved 13 May 2020, https:// covid19.fmoh.gov.ba/uploads/files/Naredba-1203-05e2bo81144fe3e343d84f7bbfb89dd 3obec8oog.pdf.

43 Riyasat of the IC in BiH - Directorate for Religious Affairs, Information on the Instruction of ra'is al-'ulama' on acting during the epidemiological situation caused by coronavirus, no. 03-03-1-1322/20 of 12 March 2020.

44 Instruction of ra'is al-'ulama' on acting of organizational units, organs, institutions, and other juridical persons of the IC in $\mathrm{BiH}$, no. 01-03-1-1313/20 of 12 March 2020.

45 Stavovi, uputstva i preporuke Vijeća muftija u vezi sa pandemijom koronavirusa [Council of muftis' views, guidelines and recommendations concerning the coronavirus pandemic] 2020. Retrieved 27 April 2020, https://www.islamskazajednica.ba/aktivnosti-vijeca/28741 -stavovi-uputstva-i-preporuke-vijeca-muftija-u-vezi-sa-pandemijom-koronavirusa. 
committees. The instruction required that a "clear mosque closure notice" be displayed on the door of each mosque. ${ }^{46}$

Since the COVID-19 pandemic has continued during the holy month of Ramadan, the distinct challenge for the IC was to reconcile religious rituals and social gatherings during Ramadan with the lockdown. ${ }^{47}$ The Guidelines on organization of religious activities during Ramadan in the conditions of the pandemic of the Riyasat represent an attempt to achieve a balance between preservation of "the continuity of Ramadan rites" and compliance with public health directives. The guidelines were carefully designed after the series of consultations of the Riyasat with the representatives of the state authorities and experts in the field of epidemiology and public health. ${ }^{48}$ According to this document, mosques have remained closed during Ramadan for large gatherings, and the faithful have been guided to substitute mosque attendance with performance of daily and Tarawih prayers in a family setting. Imams were instructed to pray the Tarawih with fewer attendees, not exceeding the number of persons allowed to gather in a public place by the public authorities. ${ }^{49}$

As state authorities eased restrictions in the middle of the month of Ramadan, because of the stable epidemiological situation, the adjustment of the IC to the pandemic entered its third phase. Mosques were open for Friday prayers and two daily prayers (zuhr and maghrib), with the obligatory observance of the measure of physical distance, hygiene, and disinfection. ${ }^{50}$

46 Ra'is al-'ulama', Instruction to imams and congregational boards for acting in circumstances of an emergency situation proclaimed owing to the coronavirus pandemic, no. 01-03-1-1433/20 of March 18, 2020.

47 The whо Interim guidelines of 15 April 2020 on "Safe Ramadan practice in the context of the Covid-19 pandemic" (available at https://apps.who.int/iris/bitstream/handle/ 10665/331767/ w HO-2019-nCoV-Ramadan-2020.1-eng.pdf?sequence =1\&isAllowed =y) were translated into Bosnian and published on the website of the IC ("Svjetska zdravstvena organizacija: Bezbjedno obavljanje ramazanskih dužnosti u kontekstu covida-19“ 2020. Retrieved 5 May 2020, https://static.islamskazajednica.ba/vijesti/aktuelno/289652020-svjetska-zdravstvena-organizacija-bezbjedno-obavljanje-ramazanskih-duznosti-ukontekstu-covid-a-19.

48 "Reisu-l-ulema razgovarao sa predsjednicom Kriznog štaba Kantona Sarajevo" [Ra'is al-'ulama' talked with the President of the Crisis Headquarters of the Canton of Sarajevo] 2020. Retrieved 5 May 2020, https://static.islamskazajednica.ba/aktivnosti-reisu-l -uleme/28907-reisu-l-ulema-razgovarao-sa-predsjednicom-kriznog-staba-ksa.

49 Riyasat of the IC, Guidelines on the organization of religious activities in the state of emergency during the month of Ramadan of 1441. Hijra year, no. 02-03-02-1718/20, 17 April 2020.

50 Riyasat of the IC, Instruction, no. 02-03-2-1719/20 of 17 April 2020. 


\subsection{The Catholic Church}

Unlike the top-down approach of the IC in the management of religious life during the pandemic, the CC adopted a more decentralized approach. Church dioceses were granted a degree of autonomy in the interpretation and elaboration of the framework Guidelines issued by the Bishops' Conference of BiH on March 13, 2020. This document emphasized the religious duty of the Catholic priests and the faithful to adhere to the state COVID-19 regulations:

As Christians, we have a duty to work with everyone who is entrusted with leading our society and caring for the health and common good of our country. That is why we need to adhere to the instructions issued by the civil authorities and relevant ministries. ${ }^{51}$

According to the Bishops' guidelines, Eucharistic celebrations or the holy masses were not suspended, but they were expected to be performed in compliance with the requirements for public gatherings, and where possible, outdoors. Elderly people and other populations at risk were advised to "think well and decide for themselves whether to attend the Eucharistic celebrations."

The Bishops' Conference's Guidelines were supplemented by circulars issued by the bishops for their dioceses, soon after the state of natural or other disaster was declared in the country and the regulations on the suspension of public gatherings were adopted. Cardinal Vinko Puljić, the Archbishop of Vrhbosna, went public on March 18, 2020, announcing The Additional instructions and provisions regarding the coronavirus pandemic. ${ }^{52}$ These provisions concerning masses, confessions and other church matters can be classified into three categories, depending on whether they relate to (a) public gatherings, (b) physical distance, or (c) hygiene measures.

Based on the state regulations prohibiting public gatherings and relevant rules of the Canon law, ${ }^{53}$ the Cardinal's Instructions were framed as religious dispensations for the faithful from taking part in congregational church

51 Bishops' Conference of BiH, Guidelines and provisions on the conduct in the situation of declared pandemic of coronavirus, no. 64/2020, 13 March 2020. Retrieved 5 May 2020, https://www.md-tm.ba/clanci/sarajevomostar-upute-i-odredbe-za-ponasanje-u-situaci ji-proglasene-pandemije-koronavirusa.

Archdiocese Vrhbosna, Additional instructions and provisions regarding the coronavirus pandemic, 18 March, 2020. Retrieved 5 May 2020, https://ika.hkm.hr/novosti/dodatne -upute-i-odredbe-u-vrhbosanskoj-nadbiskupiji-u-svezi-s-proglasenom-pandemijom -koronavirusa/.

53 See can. 87 § 1 and can. 1245, Zakonik kanonskog prava proglašen vlašću pape Ivana Pavla II s izvorima - Codex iuris canonici Auctoritate Ioannis Pauli PP. II Promulgatus Fontium Annotatione Auctus (1996). 
services. Thus, Catholic believers were granted forgiveness from their duty to attend church masses, which were held by the priests without the presence of worshippers. Congregational confessions were suspended, and all diocesan and parish catechetical and pastoral programs, meetings, and other events were canceled. ${ }^{54}$ At the same time, the Instructions provided that churches remain open for individual visits and meetings with priests, because they "play a particularly important role in the prayer and spiritual encouragement of the faithful." ${ }^{55}$ In accordance with the covid-19 regulations on physical distance and hygienic measures, confessions were not held in the confessionals but in other premises of the church, with at least one meter between the priest and the person being confessed. ${ }^{56}$ The circular issued on March 18, 2020, by the Bishop of Banja Luka, Franjo Komarica, was similar, except for the decision to postpone the sacraments until further notice, barring urgent cases (e.g., baptism, anointing of the sick, confession). ${ }^{57}$

Unlike cardinal Puljić and the bishop Komarica, Ratko Perić, the bishop of Mostar, was more critical toward the strict application of the state COVID-19 regulations on public gatherings to churches. The bishop's Circular of April 18, 2020 , in which he called on priests to open churches and celebrate holy mass ${ }^{58}$ with people, received significant public attention and caused criticism in the media. The question was raised whether the cc responded properly to the Covid-19 pandemic. ${ }^{9}$ The bishop argued that broadcasting masses through social media was not a substitute for church attendance, which provides the opportunity for the faithful to receive the holy communion. Referring to the equality argument, he criticized those who would like to prevent the faithful from attending mass in the church yards, but not doing so with citizens queueing in front of markets, pharmacies, and public institutions. Responding to

$54 \quad$ Supra note $5^{2}$.

55 Ibid.

56 Ibid.

57 Franjo Komarica, the bishop of Banja Luka, Dodatak uputama i odredbama BKBiH glede pandemije koronavirusa [Supplement to the instructions and provisions of the Bishops' Conference of $\mathrm{BiH}$ regarding the coronavirus pandemic] 2020. Retrieved 5 May 2020, https://www.biskupija-banjaluka.org/?p=25498.

$5^{8}$ Biskup Ratko Perić, "O slavlju sakramenata i 'blagoslovu poljâ' dok traje kriza koronavirusa" [On the celebration of sacraments and 'the blessing of the fields' during the crisis caused by the coronavirus] 2020. Retrieved 10 May 2020, https://www.md-tm.ba/clanci/ mostar-okruznica-o-slavlju-sakramenata-i-blagoslovu-polja-dok-traje-kriza-korona virusa.

59 Dalibor Milas, „Kako biskup Perić ignorira korona virus“ [How Bishop Perić ignores the coronavirus] 2020. Retrieved 10 May 2020, http://balkans.aljazeera.net/vijesti/kako -biskup-peric-ignorira-korona-virus. 
criticisms of the bishop's views, Željko Majić, the vicar-general of the Diocese of Mostar, stressed that civil authorities, even during the pandemic, should respect the minimum rights of the faithful to congregate, at least in the number approved for secular gatherings. ${ }^{60}$

\subsection{The Serbian Orthodox Church}

The soc, with its seat in Belgrade (Serbia), operates five dioceses in BiH: the Metropolitanate of Dabar-Bosnia, the Diocese of Zvornik-Tuzla, the Diocese of Banja Luka, the Diocese of Bihać-Petrovac, and the Diocese of ZahumljeHerzegovina. The Serbian Patriarch is the head of the soc; its highest executive and ecclesiastical authority is the Holy Synod of Bishops. ${ }^{61}$

The soc has shown less determination in limiting church activities during the pandemic and in the strict application of the state covid-19 regulations than did the other major religious communities. Part of the explanation for this approach lies in the fact that the general pattern of responses of Orthodox dioceses in $\mathrm{BiH}$ has been informed by the decisions of the highest authorities of the soc in Belgrade, which have hesitated to take a straightforward approach to the pandemic challenge. Moreover, the Bishops' Council of the soc in BiH did not take a position on the CoviD-19 pandemic, leaving the space to each individual diocese do decree its own rules. Another explanation appears to be the close relations of the Rs authorities with the Soc, which prevented them from taking more decisive action to enforce restrictions in public gatherings and movement of people on church congregations. ${ }^{62}$ A similar situation existed in the Republic of Serbia, where the government made great efforts to persuade the soc to accept the public health recommendations. ${ }^{63}$

6 Željko Majić, „Medijsko čudo: Biskup Perić otvorio crkve“ [Media miracle: Bishop Perić opened churches] 2020. Retrieved 10 May 2020, https://www.md-tm.ba/clanci/mostar -medijsko-cudo-biskup-peric-otvorio-crkve.

61 Vanja Jovanović, "Serbian Orthodox Church in Bosnia and Herzegovina", in: eds. Ifet Mustafić at al. (eds.), Religions in Bosnia \& Herzegovina: profile of religious communities and churches (2012), 101-102.

62 The soc is the only religious community specifically mentioned in the Rs Constitution (Article 28 para. 3, Official Gazette of the Rs, 21/92 - consolidated version, 28/94, 8/96, 13/96, 15/96, 16/96, 21/96, 21/02, 26/02, 30/02, 31/02, 69/02, 31/03, 98/03, 115/05, 117/05, 48/11). In a public address after meeting with Serbian president, Aleksandar Vučić, Milorad Dodik, a member of the Presidency of BiH, reported that the RS and Serbia had agreed on a ban on movement in the days of Easter, but also stressed that they were reluctant to do so, given the love they feel for the soc. See "Dodik - Vučić: Vaskrs proslaviti u svojim domovima" [Dodik - Vučić: Celebrate Easter in your homes] 2020. Retrieved 11 May 2020, https://lat.rtrs.tv/vijesti/vijest.php?id=379430.

63 Commenting on the Holy Synod of the Bishops' request to the government of Serbia to lift the ban on movement for Easter, Serbian president, Aleksandar Vučić, stated in the 
Because of the lack of synergy in the approaches of the Serbian Orthodox dioceses in $\mathrm{BiH}$, their responses to the state coviD-19 regulations ranged from incorporating these regulations into the internal church guidelines and their strict application within their jurisdiction, to ignoring the state recommendations through offering church services and attracting large groups of worshippers.

The Diocese of Zahumlje-Herzegovina, whose jurisdiction extends to parts of the territory of the RS and the Herzegovina-Neretva Canton, which had the largest number of people infected with the coronavirus in the $\mathrm{FBiH}$, adhered strictly to state regulations. ${ }^{64}$ The Diocese regularly updated information on its website about the adaptation of church life to the situation of the pandemic. As early as March 13, 2020, Bishop Dimitrije called on believers to show their civic and religious responsibility during the coronavirus pandemic to protect their lives and the wellbeing of the community. The recommendation was issued to the elderly, chronic patients, persons with weakened immunity, and those with symptoms of respiratory disease not to take part in the liturgy. It was recommended to avoid physical contacts between the priest and believers, as well as between the believers themselves while attending the liturgy. The clergy and the faithful were called upon to support "the instructions of the World Health Organization, the competent medical institutions and their family physicians," and to reduce their social contacts. ${ }^{65}$

After the introduction of more restrictive measures by state authorities, the Diocese of Zahumlje-Herzegovina responded, on March 21, with the suspension

media: "It does not occur to us to arrest the bishops and clergy ... I have a trust in the Patriarch Irinej, I will talk to him, I will beg him, I will kneel before him to explain what the state wishes". See "Vučić o crkvi: Imao sam drugačiji dogovor sa patrijarhom, podrška struci!" [Vučić on the Church: I had a different agreement with the patriarch, support for the profession] 2020. Retrieved 11 May 2020, https://mondo.rs/Info/Drustvo/a1311122/ Vucic-o-crkvi-i-uskrsu.html. Predrag Kon, the chief of the Serbian epidemiological team, offered his resignation because, among others, the Synod's aforementioned request, which according to his statement, "denies all efforts to save lives". See "Struka vrlo jasna: Odlazak u crkvu bio bi vrlo rizičan!" [The profession is very clear: Going to church would be very risky!] 2020. Retrieved 11 May 2020, https://mondo.rs/Info/Drustvo/a1311002/Koro na-virus-i-uskrs-da-li-ce-vernicima-biti-dozvoljeno-da-budu-u-crkvama.html.

64 See updated data on the confirmed cases of the coronavirus infections in the FBiH on the website "COviD-19.ba" of the Federal Ministry of Healthcare. 2020. Retrieved 11 May 2020, https://www.covid-19.ba/.

65 Eparhijazahumsko-hercegovačka, “SaopštenjevjernimaEparhijeZahumsko-hercegovačke i primorske" [Comminiqué to the faithful of the Diocese of Zahumlje - Herzegovina and the littoral] 2020. Retrieved 8 May 2020, https://eparhija-zahumskohercegovacka .com/?p=71425. 
of worship in the churches located in its territory. The faithful could receive communion individually in some churches. ${ }^{66}$ The diocese condemned the incident in a monastery, whose abbot had gathered around 120 worshipers, in violation of church guidelines and civil regulations on public gatherings, and the police had to intervene to stop the assembly. ${ }^{67}$

The second model was manifest in the Metropolitanate of Dabar-Bosnia. The circular sent to the priests and monks by Metropolitan Hrizostom on March 25 drew attention to the danger posed by the coronavirus epidemic and called on them to respond "with great pastoral and human responsibility" to save lives as a gift from God. Regarding the measures adopted by the public authorities, the Metropolitan appealed to priests and Orthodox believers

to undertake and do everything that is required of us and ultimately expected not to be, God forbid, the causes of the spread of this dangerous virus. We especially appeal and pray that this pandemic is not linked to faith and unbelief! This is a pandemic and a dangerous disease. ${ }^{68}$

Nevertheless, the guidelines of the Metropolitan regarding the organization of the church life did not appear to fully reflect the strong introductory statement about the seriousness of the pandemic. Thus, the Metropolitan decided that the Orthodox churches shall remain open, not only for individual prayers, but also for the celebration of the liturgy and the communion of Church members. The rationale for the decision emphasized the personal responsibility of believers and the duty of the Church to allow worship and provide communion for members. ${ }^{69}$

The bishop of the Diocese Zvornik-Tuzla Fotije, by contrast, urged the faithful not to fear the coronavirus and to "necessarily continue to attend our Orthodox services in Lent, because it is our strongest weapon against all diseases

66 Eparhija zahumsko-hercegovačka, „Saopštenje iz Eparhije ZHiP - 21. mart 2020.“ [Comminiqué from the Diocese of Zahumlje - Herzegovina and the littoral] 2020. Retrieved 8 May 2020, https://eparhija-zahumskohercegovacka.com/?p=71491.

67 Eparhija zahumsko-hercegovačka, „Saopštenje iz Eparhije ZHiP“, [Comminiqué from the Diocese of Zahumlje - Herzegovina and the littoral], 2020. Retrieved 8 May 2020, https:// eparhija-zahumskohercegovacka.com/?p=71672.

68 "Hrizostom milošću Božijom arhiepiskop sarajevski i mitropolit dabrobosanski Arhijerejskim namjesnicima i svom sveštenstvu i sveštenomonaštvu bogospasavane nam mitropolije Dabro-bosanske" [Hrizostom, by the mercy of God, Archibishop of Sarajevo and Metropolitan of Dabar - Bosnia] 2020. Retrieved 8 May 2020, https://www.mitropoli jadabrobosanska.org/vijest167o.html.

Ibid. 
and all earthly misfortunes." ${ }^{\prime 70}$ In one of his addresses after the liturgy, he argued that attending the church services during the pandemic cannot harm the faithful, since God is "stronger than any disease and temptation." He also pointed to the epidemics that had raged in the past, when people did not stop coming to church for "confessing and receiving communion, without fear."71

The reports on church activities published on the websites of the soc dioceses in $\mathrm{BiH}$ indicate that most of them continued to hold liturgical celebrations and administer communion during the pandemic. ${ }^{72}$ When journalists asked about the participation of a certain number of believers in the liturgies held to celebrate Easter, despite the curfew, the representative of the Diocese of Banja Luka shifted the responsibility for violating the ban on movement to the individual believers. He added that the Church has been doing its job, by caring for the spiritual health of believers in the same way that physicians cared for their physical health. ${ }^{73}$

Media articles on administering communion in the Orthodox churches in Serbia and BiH during the pandemic rekindled the old debate about whether priests should use a shared spoon to distribute sacramental bread and wine to the faithful. ${ }^{74}$ The question was raised whether the communion can be a

70 "Bijeljina - Obavještenje Eparhije zvorničko-tuzlanske" [Bijeljina - Notice of Diocese of Zvornik - Tuzla] 2020. Retrieved 29 April 2020, https://noviglas.info/2020/03/12/bijeljina -obavjestenje-eparhije-zvornicko-tuzlanske/.

71 "Episkog Fotije pozvao vjernike da se pričešćuju" [The bishop Fotije called on the believers to receive the communion], published on March 15, 2020. Retrieved 8 May 2020, https://www.eparhijazt.com/sr/news/vijesti-iz-eparhije/bogosluzenja/2479.episkop-fotije-pozvao-vjernike-da-se-pricescuju.html.

72 See, e.g., "Episkop Fotije: Vaskr je suština svih nas, suština naše vjere" [The bishop Fotije: Easter is the essence of all of us, the essence of our faith], published on April 19, 2020. Retrieved 8 May 2020, https:/www.eparhijazt.com/sr/news/vijesti-iz-eparhije/ bogosluzenja/2645.episkop-fotije-vaskrs-je-sustina-svih-nas,-sustina-nase-vjere.html; “(Obavještenje) Raspored bogosluženja u hramovima Eparhije bihaćko-petrovačke o Vaskršnjim praznicima 2020. godine" [(Communiqué) Worship services schedule in the churches of the Diocese of Bihać - Petrovac during the Easter holidays in 2020], published April 16, 2020. Retrieved 8 May 2020,https://www.eparhijabihackopetrovacka .org/obavjestenjeraspored-bogosluzenja-u-hramovima-eparhije-bihacko-petrovacke-o -vaskrsnjim-praznicima-2020-godine/.

73 "Crkva o kršenju mjera za vrijeme Vaskrsa: Apelovali smo na vjernike da se pridržavaju mjera, mi smo radili svoj posao" [Church on the violation of the measures during Easter: We appealed to the faithful to adhere to the measures, we did our job] 2020. Retrieved 11 May 2020, http://www.gerila.info/naslovna/crkva-o-kresenju-mjera-za-vrijeme-vaskrsa -apelovali-smo-na-vjernike-da-se-pridrzavaju-mjera-mi-smo-radili-svoj-posao/.

74 "Crkva se oglušila o mere protiv korone i u Istočnom Sarajevu: Vernici se pričešćivali jednom kašičicom usred epidemije" [Church ignored the measures against the coronavirus also in the Eastern Sarajevo: The faithful shared one spoon during the communion amid 
source of transmission of the coronavirus infection. According to Miroslav Aleksić, an Orthodox theologian and religious teacher, there are two views on this issue in the soc. One group of Orthodox theologians, bishops, and priests believes that communion should not be given to believers from one spoon during the pandemic, whereas another group of theologians, bishops and, priests argues that it is not possible to transmit any infection or disease through communion. ${ }^{75}$ The former adopt the opinion of health experts, whereas for the latter, it is primarily a theological issue.

Responding to criticism about communion during the pandemic, the soc Holy Synod argued that the issue falls within the domain of church autonomy and that "the state does not deal with, nor can it deal with the content and manner of conducting the Divine liturgy or other church services." It also stated that the faithful voluntarily received the communion, and that it was "both unreasonable and utterly malicious that the Church itself would deny to its believers that which they deem most important and sacred - Holy Communion." 76

\subsection{The Jewish Community}

The JC consists of the six Jewish municipalities (Sarajevo, Banja Luka, Tuzla, Doboj, Mostar, and Zenica) and the Jewish cultural, educational, and charitable society, "La Benevolencia." The highest administrative body of the JC is the Community Council, consisting of the presidents of the Jewish municipalities and the representative of "La Benevolencia." They elect the Community Council president from among them, who represents the JC. Although the JC belongs to minority religions in $\mathrm{BiH}$, it is recognized as a traditional religious community because of its long historical presence in $\mathrm{BiH}$, dating back to the 16th century. ${ }^{77}$

the pandemic] 2020. Retrieved 11 May 2020, https://www.kurir.rs/region/bosna-i-hercegovina/3448665/crkva-se-oglusila-o-mere-protiv-korone-i-u-istocnom-sarajevu-vernici -se-pricescivali-jednom-kasicicom-usred-epidemije.

75 Dušan Komarčević, "SPC i jedna kašičica za vernike i u pandemiji" [The soc and one spoon for the faithful even during the pandemic] 2020. Retrieved 9 May 2020, https:// www.slobodnaevropa.org/a/spc-jedna-ka\% $\mathrm{C}_{5} \%$ Ai1\%C4\%8Dica-i-mnogo-neodgovor nosti/30506715.html.

76 Communiqué of the Holy Synod of Bishops of the Serbian Orthodox Church, published on March 23, 2020. Retrieved 9 May 2020,http://www.spc.rs/eng/communique_holy _synod_bishops_o.

77 For more details on the Jc, see Boris Kožemjakin, "Jevrejska zajednica Bosne i Hercegovine" [The Jewish Community of Bosnia and Herzegovina], in Ifet Mustafić et al. (eds.), Religions in Bosnia and Herzegovina: profile of religious communities and churches (2012), $177^{-217}$. 
The Jc has a large number of elderly members, therefore the focus of its activities during the pandemic has been to organize a network of volunteers to assist these members in obtaining food and medicine, given the ban on movement of persons over 65 years. All JC congregational prayers and educational programs for children were suspended, together with all visits to the Museum of the Jews in Sarajevo. ${ }^{78}$

This year, the Jews did not gather at the Ashkenazi Synagogue in Sarajevo for Passover, the biggest Jewish festival, because of the pandemic. On the eve of the festival, Igor Bencion Kožemjakin, the hazzan of the Sarajevo synagogue, ${ }^{79}$ distributed unleavened bread to Jewish families, together with a festival prayer in the Latin alphabet for those who do not read Hebrew. Seder, the solemn feast that marks the beginning of Passover, was held in close family settings. The hazzan Kožemjakin made recordings of his Passover and Shabbat evening services and broadcasted them online. ${ }^{80}$

\section{Inner-religious Argument for Restricting Religious Gatherings and} Rituals

This section seeks to identify the theological arguments or norms of religious laws used to justify the above restrictions in the eyes of the believers.

In the IC guidelines, the suspension of congregational prayers in mosques, including the Friday prayer, and the adaptation of other forms of religious life to the conditions of the pandemic, were argued by references to the Qur'an and the Sunnah, as the two primary sources of Islam; the higher intent of Islamic law to protect human life (maqsad hifz al-nafs); and the consensus $(i j m a)$ of Islamic jurists that the believer is relieved of the duty to take part in congregational prayers and the Friday prayer if he faces a threat to his life. ${ }^{81}$

78 Edib Bajrović and Meliha Kešmer, "Poruke vjerskih lidera u vrijeme pandemije” [Messages of religious leaders in pandemic times] 2020. Retrieved 9 May 2020, https://www.slo bodnaevropa.org/a/poruka-vjerskih-lidera-korona-virus/30507110.html.

79 The only active synagogue in Sarajevo does not have an officiating rabbi.

8o "In Sarajevo, a small community draws on its wartime experience to survive covid-19" 2020. Retrieved 15 June 2020, https://eurojewcong.org/news/communities-news/bosnia -herzegovina/in-sarajevo-a-small-community-draws-on-its-wartime-experience-to-sur vive-covid-19/; Armin Aljović, „Kožemjakin: Prvi Pesah bez vjernika u sarajevskoj sinagogi“ [Kožemjakin: The First Passover without the Believers in Sarajevo synagogue] 2020. Retrieved 15 June 2020, http://balkans.aljazeera.net/vijesti/kozemjakin-prvi-pesah -bez-vjernika-u-sarajevskoj-sinagogi.

81 Supra notes 44-46; Vijeće muftija, "Fetva o načinu obavljanja dnevnih namaza i džumenamaza tokom pandemije koronavirusa" [Fatwa on the way of performing daily prayers and the Jumu'a prayer during the coronavirus pandemic] 2020. Retrieved 9 May 2020, 
The Qur'anic verses calling for the protection of life were quoted: And if anyone saved a life, it would be as if he saved the life of all mankind; ${ }^{82}$ And do not throw yourselves into destruction; 83 And do not kill yourselves (nor kill one another), ${ }^{84}$ together with the hadith that commands believers to act responsibly to prevent the spread of the infection: "If you hear that a dangerous contagious disease has appeared in a country, do not enter it. If it appears in the country you are in, don't run away from it." ${ }^{85}$

Of the five higher intents of the Islamic normative system (maqasid alShari' $a$ ), the protection of human life comes is first. When there is a conflict between the expression of belief and the performance of religious duties on one hand, and the protection of human life on the other, preference is given to the latter. The protection of life inevitably presupposes the protection of health, which in a situation of pandemic forces believers to listen to recommendations seeking to prevent the spread of infection.

The cc guidelines on church life in pandemic times stressed that care for "health and general wellbeing in our country" was a Christian obligation, and called for personal and family prayer to God to help those suffering from the virus, those caring for the sick, and for emerging from the pandemic, which was described as a divine temptation for humans. ${ }^{86}$ The suspension of masses was justified by reference to provisions of the Codex Iuris Canonici, which authorize the diocesan bishop to grant the faithful forgiveness for not participating in Sunday mass if it contributes to their wellbeing. ${ }^{87}$ Believers were advised to respond to the coronavirus threat with both faith and reason (fides et ratio), divine graces that stand in a complementary rather than contradictory relationship. While reason tells that the matter of the Eucharist, the bread, can be a transmitter of the virus, faith tells that the believer, by receiving the communion, "eats the body of Jesus", achieving unity with him. Thus, faith dictates that this sacrament not be denied to anyone who wishes to receive it, while reason requires minimizing the possibility of transmitting the infection by touch during communion. ${ }^{88}$

\footnotetext{
https://www.islamskazajednica.ba/fetve-i-rezolucije/2883o-fetvu-o-nacinu-obavljanja -dnevnih-namaza-i-dzume-namaza-tokom-pandemije-koronavirusa.

82 The Qur'an, chapter 5 , verse 32.

83 The Qur'an, chapter 2, verse 195 .

84 The Qur'an, chapter 4, verse 29.

85 This report was included in the two most authentic collections of hadiths, Sahih alBukhari and Sahih al-Muslim.

86 Supra note 51.

87 Supra note 52.

88 "Poruka mons. Ratka Perića povodom pandemije koronavirusa" [Message of Monsignor Ratko Perić on the occasion of the coronavirus pandemic], published on March 19, 2020.
} 
The instructions of the Serbian Orthodox dioceses in BiH concerning the coronavirus pandemic urged Orthodox believers to protect life as a gift from God and to show Christian love and empathy for the infected, but "also for those who were not infected." They referred to the example of Christ, who "seeing that the scribes and Pharisees and members of the Sanhedrin were plotting against him," passed between them and left. Believers were advised to follow the example of Christ, and take refuge from the coronate "until it loses its strength and is defeated." 89 By assuming a responsible stance in the coronavirus pandemic, Orthodox believers attest to their faith in Christ with love and care for others. As written in one church statement, "what should motivate us to be careful is not only caring for our own lives that God has bestowed us, but also the responsibility for the wellbeing of our loved ones." ${ }^{90}$

\section{Conclusion}

In societies with high rates of religiosity, such as $\mathrm{BiH}$, religious institutions and leaders can play an important role in shaping the attitudes of people toward public health recommendations aimed to combat a pandemic like covid-19. Three religious communities (the IC, the SOC, and the CC) dominate the religious landscape of Bosnian society and play an important role in the collective identity of the three Bosnian ethnicities: Bosniaks, Serbs, and Croats.

To cope with the challenge of the CoviD-19 pandemic, BiH and its entities declared a state of natural disaster (a state of emergency) and adopted several public health regulations to prevent the spread of the infection. Some of these regulations, especially those that suspended public gatherings and the movement of people, restricted religions. The decision of the Constitutional Court of $\mathrm{BiH}$ in case AP-1217/20, which established the violation of the right to freedom of movement of persons affected by the state CoviD-19 regulations, enables us to conclude that public authorities are required to balance the protection of health during the pandemic with limitations placed on the constitutional human rights and freedoms, including freedom of religious assembly.

Responding to the enactment of the state CoviD-19 regulations, religious communities in $\mathrm{BiH}$ have adopted their own guidelines and recommendations for their staff and believers to adapt religious rites and gatherings to the new

Retrieved 12 May 2020, https://ika.hkm.hr/bk-bih/poruka-msgr-ratka-perica-povodom -pandemije-koronavirusa/\#.

89 Supra note 68.

9o Supra note 65. 
circumstances caused by the pandemic. Religious leaders and the highest bodies sent a message to the public about the importance of socially responsible behavior under the circumstances of the pandemic, and called on the faithful to comply with the public health recommendations.

Not all religious communities were equally supportive of the state regulations that placed restraints on religious freedom. While some communities were ready to incorporate the state CoviD-19 regulations into their own guidelines and practices, others found it difficult to reconcile the state regulations with their autonomy in administering church life.

Our research has shown that all religious communities managed to find resources in their holy books, religious laws, and theological views to support the restrictions. What is common in the arguments of all religious communities is the emphasis on the value of human life and the virtue of caring for the wellbeing of the community. 